\title{
DEVELOPMENT OF PLANTER FOR MINIMIZING ROW SPACES AND MAXIMIZING THE SUGAR BEET YIELD
}

Marey S.A. *

\author{
R.M. Kholief**
}

W.A. Gad ${ }^{* * *}$

\section{ABSTRACT}

The aim of the present study is to modificate sugar beet planter row spacing from $60 \mathrm{~cm}$ to $50 \mathrm{~cm}$ comparing with $40-60 \mathrm{~cm}$ row space (double furrows) using three different geometric shapes of opener with four levels of planting speed. The effect of study parameter were evaluated in terms of number of plants per feddan, seed scattering, root and sugar yield and water use efficiency. The modifications were conducted at workshop of Delta sugar Co., El-Hamool Factory while the field experiments were conducted at private Gad's farm, Kafr El-Sheikh Governorate using Montbuanco variety during growing season of 2006/2007. The main results can be summarized as follow:

-The minimum values of seed scattering were obtained with 40$60 \mathrm{~cm}$ row space comparing with other spaces at forward speed of $2.25 \mathrm{~km} / \mathrm{h}$ and opener $(A)$.

-The highest values of number of plants per feddan and water use efficiency were 44900 plant/fed. and $0.0173 \mathrm{Mg} / \mathrm{m}^{3}$ with $40-60 \mathrm{~cm}$ row space at forward speed of 2.25 and $3.5 \mathrm{~km} / \mathrm{h}$, respectively with opener (A). flowed by $50 \mathrm{~cm}$ row space at the same conditions. While the lowest one was obtained with 60 $\mathrm{cm}$ row space and forward speed of $7.4 \mathrm{~km} / \mathrm{h}$ when using opener (B).

- Maximum values of sugar and root yield were obtained with $50 \mathrm{~cm}$ row space, machine speed of $3.5 \mathrm{~km} / \mathrm{h}$ and opener (A). But the minimum values were obtained with $60 \mathrm{~cm}$ row space, machine speed of $7.4 \mathrm{~km} / \mathrm{h}$ and opener $(B)$.

- Increasing the forward speed from 2.25 to $7.4 \mathrm{~km} / \mathrm{h}$ tends to

* Researcher, Ag. Eng. Res., Inst., (AEnRI),El-Giza, Egypt.

** Senior Researcher, Ag. Eng. Res. Inst. (AEnRI),El-Giza, Egypt. *** Doctor - Research Dept., - Delta sugar Co., El-Hamool., - Kafr El-Sheikh - Egypt. 
increase longitudinal, transverse scattering, root diameter and length by $144.44,181.25,11.32$ and $15.45 \%$, respectively at 50 $\mathrm{cm}$ row space and opener $A$, but the number of plants per fed., sugar and root yield, decreased by 24.71,22.98 and 26.09, \% respectively at the same above conditions.

\section{INTRODUCTION}

Tost sugar beets in Egypt are grown on raised planting beds to facilitate furrow irrigation. The most common row arrangements are single rows centered on beds 60 $\mathrm{cm}$ apart. The later arrangement results in an alternating row spacing of 40-60 cm.

Increasing number of growers are planting to a stand. Because of hazards to emergence, the growers plant as many seeds as possible consistent with a plan to establish a stand that will not require thinning. It is common to find stands where plants average $10 \mathrm{~cm}$ and closer within the row. Farmers have been interested in growing sugar beets in wider rows because field equipment can be used for more than one crop with minimal adjustment. There have been many studies on the effect of plant population on sugar beet production.

Hull and Jaggard (1971) mentioned that greatest sugar yield are given by population of 26000 to 34000 plants per acre (24960 to 32640 plant/fed.) but that urinations of several thousand per acre generally have only small effects on yield.

Robinson and Worker (1969) confirmed earlier studies that a 12inch square spacing (43500 plants/acre) yielded maximum sucrose. 24 inch square spacing yielded about $7.0 \%$ less sucrose; but 3 inch spacing resulted in $50 \%$ loss.

Agness and Luth (1975) found that most criteria for planter design have included such factors as population control, accuracy of seed spacing in the row, seed depth and seed soil contact. However, the amount of damage that planter meter may cause to sugar beet may be one of the most critical factors to consider in its design. 
Fornstrom and Jackson (1983) indicated that sugar beet grown in $56 \mathrm{~cm}$ rows yielded $3.4 \mathrm{Mg} / \mathrm{ha}$ more than sugar beets grown in $76 \mathrm{~cm}$ rows when plant to stand, minimum labor practices were used. Higher yield were obtained from a seeding rate of 84500 and 110000 seeds/ha (35490 and 46200 seeds/fed.) than from a seeding rate of 166000 seeds/ha.(69720 seeds/fed.)

Singh and Thakur (1979) stated that when sugar beet is planted manually, the required number of seeds on each hill is difficult to control and at some place more seeds are dropped than desired. This consumes more time and energy at the time of thinning and singling the plant. The drill distributes the seed uniformity and there fore it is easier to take out unwanted plants.

Cattanach and Schrooder (1980) indicated that sugar yields average $660 \mathrm{~kg} / \mathrm{ha}(277.2 \mathrm{~kg} / \mathrm{fed}$.) greater for narrow rows (46 to $56 \mathrm{~cm})$ than that for wider rows $(58-76 \mathrm{~cm})$.

Giles et al. (1990) investigated the effect of increasing ground speed on performance of various commercial sugar beet planters and on subsequent production of recoverable sugar. Data were collected from drills mounted on a test stand and from field studies at 5 locations over a 2 years period. Ground speed range use from 1.34 to $2.24 \mathrm{~m} / \mathrm{s}$ with seed spacing at 63.5 and $127 \mathrm{~mm}$ for all drill types evaluated, significant decreases in seeding percentage occurred as ground speed increased. A slower ground speed resulted in significant increase in root yield, recoverable sugar and sugar percentage. Seed emergence increased by slower ground speed. Increased seed spacing reduced sugar production.

Lenka (1991) showed that the furrows stream would be large that it reaches the lower end in desired time to avoid on ding and excess opportunity time. In many cases, erosion takes place in furrows. Limit of erosion in the furrow permissible depends upon the type of soil. Schwab et al. (1993) reported that furrows of 80 to $200 \mathrm{~mm}$ deep are especially suited to row crops since the furrow can be constructed with normal tillage. Contour furrow irrigation may be practiced on slopes up to 12 percent, depending 
on the crop, the readability of the soil and the size of the irrigation stream reduce operational drudgery.

Taieb (1997) found that the mechanical planting of sugar beet saved $33 \%$ of seeds compared with the manual planting. The mechanical planting of sugar beet decreased the cost of the consumed energy by 58\%. The mean yield values were 29.22 and $34.38 \mathrm{Mg} / \mathrm{fed}$. with manual and mechanical planting, respectively.

The objective of the present study was to develop a Gaspardo Seminatrici planter for closing in-row spacing and comparing 50, $60 \mathrm{~cm}$ with $40-60 \mathrm{~cm}$ on sugar beet yield.

\section{MATERIALS AND METHODS}

The development of Gaspardo Seminatrici S.P.A. planter was executed at workshop of Delta sugar Co., Kafr ElSheikh factory and was tested in Gad's farm of Monshat Abass, Kafr El-Sheikh Governorate, Egypt during winter season of 2006/2007.

The modification process accomplished through out manufacture one beam to fix furrow openers separated on planting units and three hitch points attached with beams as shown in Plate 1. This unit was fixed on the planter in simple texture to available using the planter in other crops after separating this unit. This development allowed the planter to plant sugar beet seeds in row spacing of $50 \mathrm{~cm}$ while the minimum row spacing before development operations was $60 \mathrm{~cm}$. Plate 1 shows the planter before and after modification and its characteristics are shown in Table 1.

The experimental field area was about 2 feddans were divided into three main plots for 50, 60 and 40-60 cm row spaces, each plot was divided into three sub plots for opener shape, each sub plots was divide into four sub sub plots for planter forward speeds. The field was prepared by using chisel plough twice and LASER land leveling. Kubota tractor of $67.2 \mathrm{~kW}$ power at $2600 \mathrm{rpm}$ was used as a mobile power for the chisel plough, scraper and sugar beet planter. All agricultural operations such as fertilizing, irrigation and best control were performed according to technical 
recommendations prevailed in the area of the experiment. The mechanical analysis data of experimental soil are shown in Table (2). The previous crop was rice. Sugar beet Multigerms (Montbuanco-variety) was sown in $15^{\text {th }}$ September 2006 and harvested in $13^{\text {th }}$ April 2007.

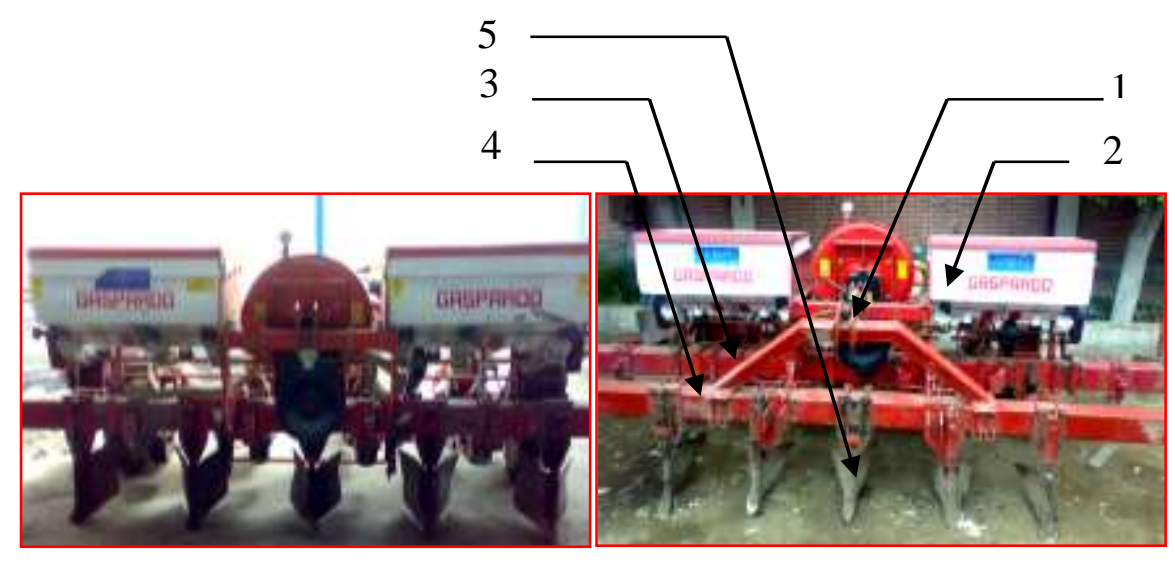

a. Before modification.

b. After modification.

1. Hitch point.

3. Original tool bar.

5. Furrow opener.
2. Fertilizer hoper.

4. Ridger tool bar.

Plate (1): The planter before and after modification.

Table 1: characteristics of the planter before and after modification

\begin{tabular}{|l|c|c|}
\hline \multicolumn{1}{|c|}{ Characteristics } & $\begin{array}{c}\text { Before } \\
\text { modification }\end{array}$ & $\begin{array}{c}\text { After } \\
\text { modification }\end{array}$ \\
\hline \multicolumn{1}{|c|}{ Type } & Gaspardo Seminatrici S.P.A. \\
\hline Manufacture country & \multicolumn{2}{|c|}{ Italy } \\
\hline Number of rows & \multicolumn{2}{|c|}{4} \\
\hline Number of beams & \multicolumn{2}{|c|}{2.5} \\
\hline Toolbar width, m & 0.6 & 0.5 \\
\hline Row distance, m & \multicolumn{2}{|c|}{540} \\
\hline PTO, rpm & 550 \\
\hline Power required, $\mathrm{kW}$ & \multicolumn{2}{|c|}{32} \\
\hline Weight, kg & \multicolumn{2}{|c|}{320} \\
\hline Seed hoper capacity, 1 & \\
\hline Fertilizer hoper capacity, 1 &
\end{tabular}


Table 2: Some mechanical analysis of soil before carrying out ploughing operation

\begin{tabular}{|c|c|c|c|}
\hline \multicolumn{3}{|c|}{ Particle size distribution } & \multirow{2}{*}{ Soil type } \\
\cline { 1 - 2 } Sand, \% & Silt, \% & Clay, \% & Clay loam \\
\hline 17.13 & 30.56 & 52.31 & \\
\hline
\end{tabular}

\section{Study parameters:}

1.Three row spacing of $50,60 \mathrm{~cm}$ row space and $40-60 \mathrm{~cm}$ as shown in Fig. 1.

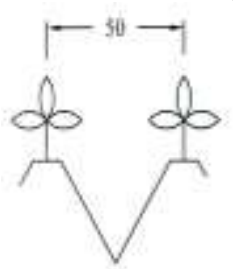

(a)

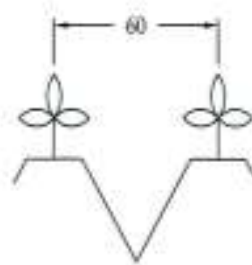

(b)

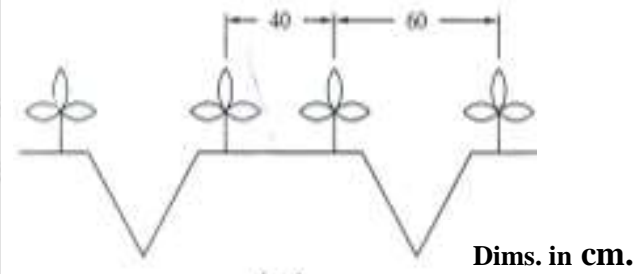

(c)
(a) $50 \mathrm{~cm}$ rows space
(b) $60 \mathrm{~cm}$ rows space
(c) $40-60 \mathrm{~cm}$ rows space

Fig. 1: Sugar beet rows spacing.

2. Four forward speed of $(2.25,3.50,5.50$ and $7.4 \mathrm{~km} / \mathrm{h})$

3. Three opener shapes (A, B and C) as shown in Fig. (2).

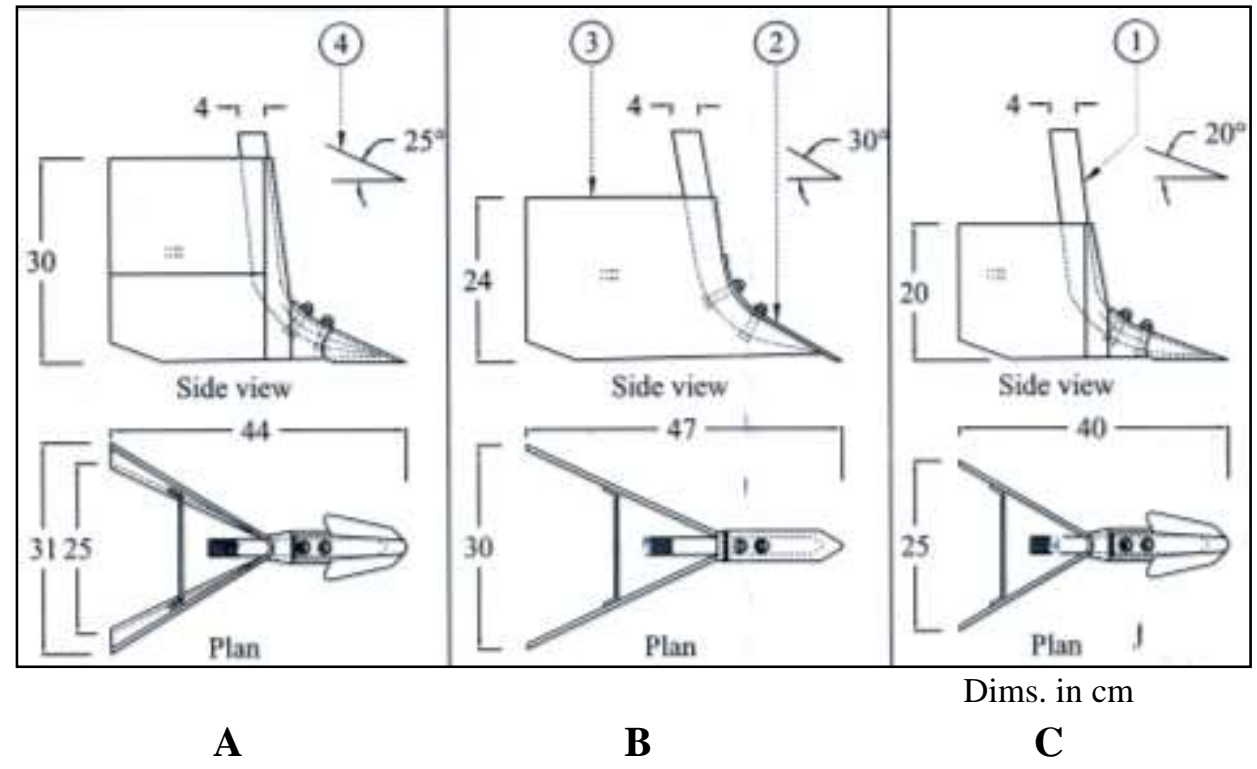

Fig. 2: Three shapes of opener (A, B and C). 
-The opener (A) is a ridger with shovel share, curved-shape wings, $25 \mathrm{~cm}$ in width, $44 \mathrm{~cm}$ in length, $30 \mathrm{~cm}$ in height and...0.436 rad. (25deg) penetration angle, opener (B) is a ridger with hoe share, striate wings, $30 \mathrm{~cm}$ in width, $47 \mathrm{~cm}$ in length, $24 \mathrm{~cm}$ in height and 0.523 rad. (30 deg.) penetration angle and opener (C) is a ridger with shovel share, striate wings, $25 \mathrm{~cm}$ in width, $40 \mathrm{~cm}$ in length, $20 \mathrm{~cm}$ in height and $0.349 \mathrm{rad}$. (20 deg) penetration angle.

It must be denoted that the opener $\mathrm{C}$ is the original one.

\section{Measurements:}

During conducting the experiments the following items were measured:

\section{Longitudinal and transverse scattering calculation:}

The longitudinal scattering of seeding placement was determined statistically by the standard deviation of the distance between seedlings within the row by using the following formula:

$$
\xi_{n-1}=\sqrt{\frac{\Sigma \mathrm{X}^{2}-(\Sigma \mathrm{X})^{2} / \mathrm{n}}{\mathrm{n}-1}}
$$

Where:

$\zeta_{\mathrm{n}-1}=$ Standard deviation, $\mathrm{cm}$;

$\mathrm{X}=$ Distance between hills within the row, $\mathrm{cm}$; and

$\mathrm{n} \quad=$ Number of observations;

Also; the scattered seeding around the centerline of row measured and used the previous equation (equation 1) to calculate transverse scattering.

\section{Root and sugar yield in $\mathrm{Mg} / \mathrm{fed}$;}

The yield of the harvested roots $\left(\mathrm{R}_{\mathrm{y}}\right)$ was determined by massing the roots lifted by a manual shovel, during manual harvesting use, the following equation (Taieb, 1997) was used sa follows:

$$
R_{y}=\frac{\mathrm{M} \times 4200}{\mathrm{~A} \times 1000}, \mathrm{Mg} / \mathrm{fed} .
$$

Where:

$$
\begin{array}{ll}
\mathrm{M} & =\text { The mass of lifted root, } \mathrm{kg} ; \text { and } \\
\mathrm{A} & =\text { The harvested area, } \mathrm{m}^{2} .
\end{array}
$$

.Sugar yield per feddan equals to root yield per fed. in $\mathrm{Mg}$ multiplied by sucrose percentage. 


\section{Sucrose percentage, $\%$ :}

The sucrose percentage was measured in Laboratory of El-Hamool Factory; Delta sugar Co. It was estimated polarimertically on a lead acetate extract of fresh macerated roots.

\section{Field water use efficiency:}

The field water use efficiency (FWUE) was calculated according to the following equation (Michael, 1978):

$$
\mathrm{FWUE}=\frac{\mathrm{Y}}{\mathrm{W}}, \mathrm{Mg} / \mathrm{m}^{3}
$$

Where:

$$
\begin{array}{ll}
\mathrm{Y} & =\text { Yield, } \mathrm{Mg} / \mathrm{fed} . ; \text { and } \\
\mathrm{W} & =\text { Total amount of water applied, } \mathrm{m}^{3} / \text { fed. }
\end{array}
$$

\section{Applied irrigation water:}

The volume of water applied for each feddan was calculated using the following equation, (Eid, 1988).

$$
\mathrm{Q}=\mathrm{q} \times \mathrm{t} \times \mathrm{n}
$$

Where:

$$
\begin{array}{ll}
\mathrm{Q} & =\text { Applied irrigation water, } \mathrm{m}^{3} / \mathrm{fed} ; \\
\mathrm{q} & =\text { Discharge, } \mathrm{m}^{3} / \mathrm{min} . \\
\mathrm{t} & =\text { Total irrigation time, min./fed.; and; } \\
\mathrm{n} & =\text { Number of irrigations per season. }
\end{array}
$$

\section{RESULTS AND DISCUSSION}

\section{Longitudinal and transverse seed scattering:}

Fig. 3 illustrate the effect of row space, forward speed and opener shape on longitudinal and transverse seed scattering. It can be stated that the increase of forward speed from 2.25 to $7.4 \mathrm{~km} / \mathrm{h}$ increases the longitudinal scattering by 194.44, 210.53 and 147.06 $\%$ for row spaces of 50, 60 and 40-60 cm, respectively when using opener (A). However the transverse scattering increased by $181.25,138.89$ and $220.00 \%$ under the same mentioned above conditions, respectively. This may be due to more slip occurred at high speeds. On the other hand the same trend for both longitudinal and transverse scattering was obtained for the two various shapes of opener (B) and (C) where the maximum values 
of longitudinal and transverse scattering were 5.9 and $5.0 \mathrm{~cm}$, respectively at forward speed of $7.4 \mathrm{~km} / \mathrm{h}$ and $60 \mathrm{~cm}$ row space when using opener (B) Also, the minimum values of longitudinal and transverse scattering seems to be lower at forward speed of $2.25 \mathrm{~km} / \mathrm{h}$ where they reached 1.2 and $1.00 \mathrm{~cm}$, respectively for opener (A) and row space of $40-60 \mathrm{~cm}$. This may be attributed to decrease the number of furrow openers in case of $40-60 \mathrm{~cm}$ (half number), which reduces the impact between the opener and clods and subsequently reduces the machine vibrations.

\section{Number of plants per feddan:}

Fig. 4 shows the effect of row space, forward speed and opener shape on number of plants per fed. It is evident that, the increase of forward speed from 2.25 to $7.4 \mathrm{~km} / \mathrm{h}$ decreased the number of plant/fed. From 43780 to 32960,41550 to 30490 and 42397 to 31839 for opener shape A, B and C, respectively at row space of $50 \mathrm{~cm}$ (after modification). Meanwhile, they were decreased from 37213 to 28050,35109 to 25611 and 35200 to 26426 for the same above-mentioned openers at row space of $60 \mathrm{~cm}$ (before modification). On the other hand, the number of plants/fed. decreased from 44900 to 34010,42770 to 31310 and 43810 to 33020 at the same above conditions, respectively with row space of $40-60 \mathrm{~cm}$.

Regarding to the opener shapes, it is worthy to mention that at all forward speeds and row spaces, the opener (A) achieved the highest values of number of plants/fed. Followed by opener (C), while the lowest values were obtained with opener (B).The cause of this trend may be due to ridge form, which decrease the amount of water around the seeds consequently increased the seed germination ratio. 


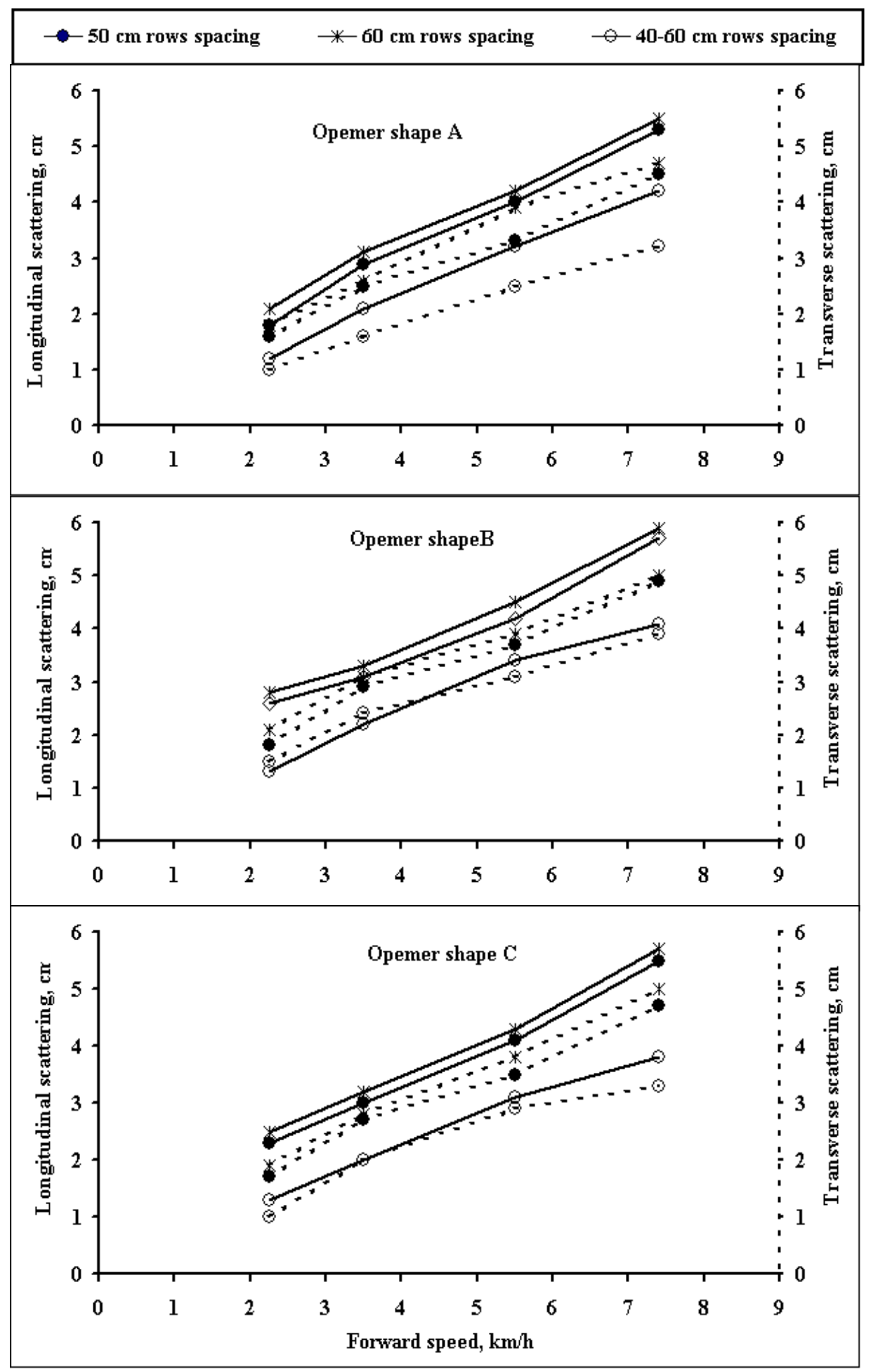

Fig. 3: Longitudinal and transverse scattering as affected by row space and forward speed at different opener shapes.

Misr J. Ag. Eng., October 2008 


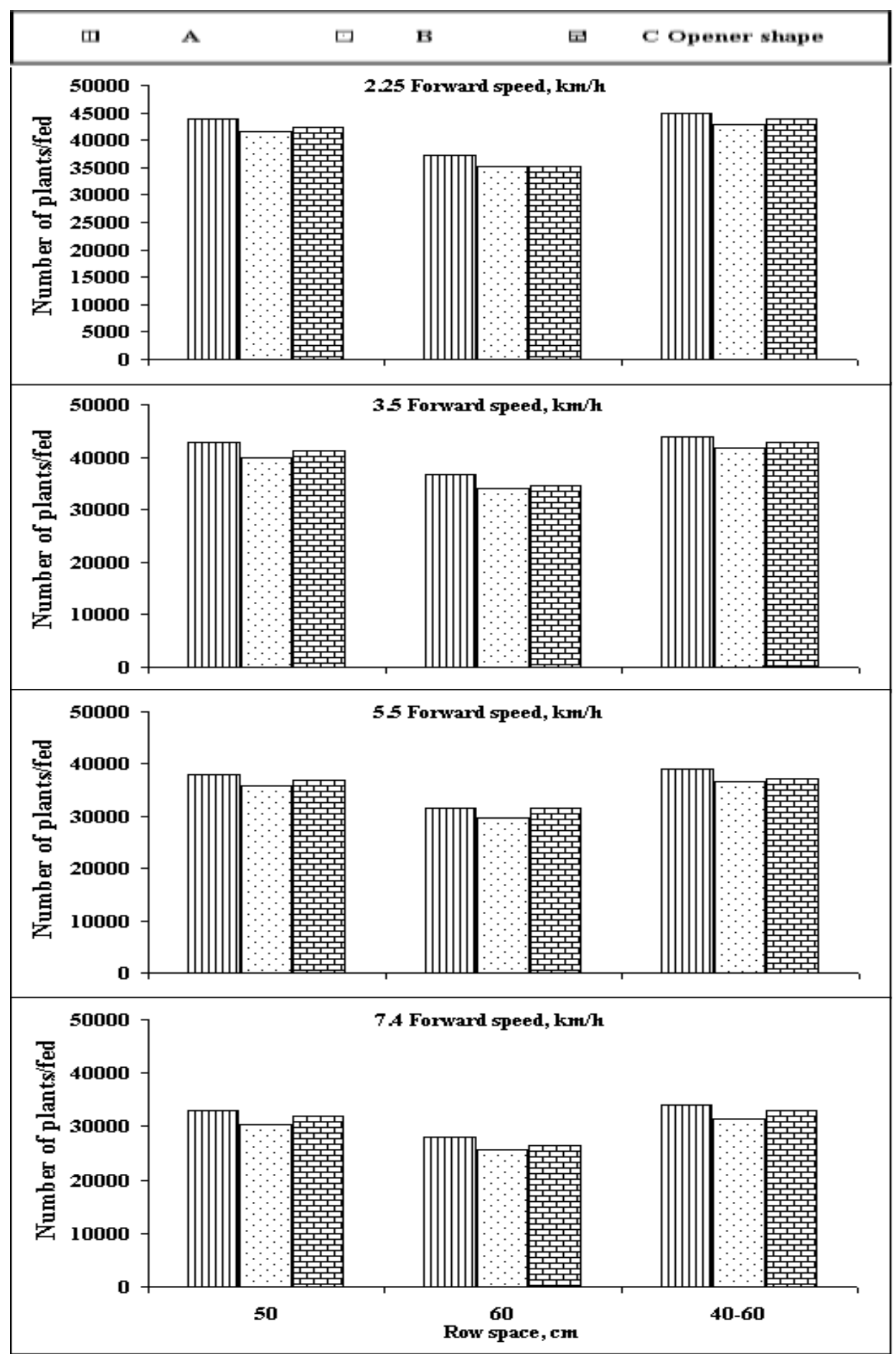

Fig. 4: Number of plants as affected by row space and opener shape at different forward speeds.

Misr J. Ag. Eng., October 2008 


\section{Yield and yield components:}

\subsection{Root length and diameter:}

Fig. 5 illustrates the root length and diameter, which was affected by, forward speed, row space and opener shape. The results indicated that increasing the forward speed from 2.25 to $7.4 \mathrm{~km} / \mathrm{h}$ the root length increased from 26.5 to $29.5,27.10$ to 30.30 and 25.6 to $28.3 \mathrm{~cm}$, at 50,60 and $40-60 \mathrm{~cm}$ row spaces, respectively for opener (A). The other two openers had the same above trend.

With respect to opener shape, it can be noticed that at all study parameters, the maximum values of root length and diameter were recorded with opener (A) as a compared with other shapes. This may be due to height of row subsequently the plant root is easier to penetrate through the soil with decrement in the soil strength.

The results also, indicated that the maximum values of root diameter and length were obtained with row space of $60 \mathrm{~cm}$ and furrow opener (A) at forward speed of $7.4 \mathrm{~km} / \mathrm{h}$ While, the lowest values were obtained with $40-60 \mathrm{~cm}$ and opener (B) at forward speed of $2.25 \mathrm{~km} / \mathrm{h}$ This may be due to decrease the number of plants/fed. in $60 \mathrm{~cm}$ row space subsequently each plant occupied a suitable area.

\subsection{Root and sugar yield:}

Fig. 6 shows the effect of forward speed and opener shape on root and sugar yield for the different spaces. The results showed that, increasing the forward speed from 2.25 to $7.4 \mathrm{~km} / \mathrm{h}$ the root yield decreased from 26.530 to $20.432,21.398$ to 15.532 and 24.317 to $17.258 \mathrm{Mg} / \mathrm{fed}$. at row space of 50,60 and $40-60 \mathrm{~cm}$, respectively when using opener (A). While the sugar yield decreased from 4.882 to $3.608,3.712$ to 2.609 and 4.180 to 2.911 $\mathrm{Mg} / \mathrm{fed}$. under the same a above mentioned conditions, respectively. In the same manner the other two openers had the same above trend.

It is obvious that, the forward speed of $3.5 \mathrm{~km} / \mathrm{h}$ achieved the highest values of root and sugar yield compared with the other forward speeds under all conditions. This may be due to the suitability and regularity of the number of plants per feddan. Meanwhile, the lowest values of root and sugar yield were obtained by using forward speed of about $7.4 \mathrm{~km} / \mathrm{h}$ compared with 


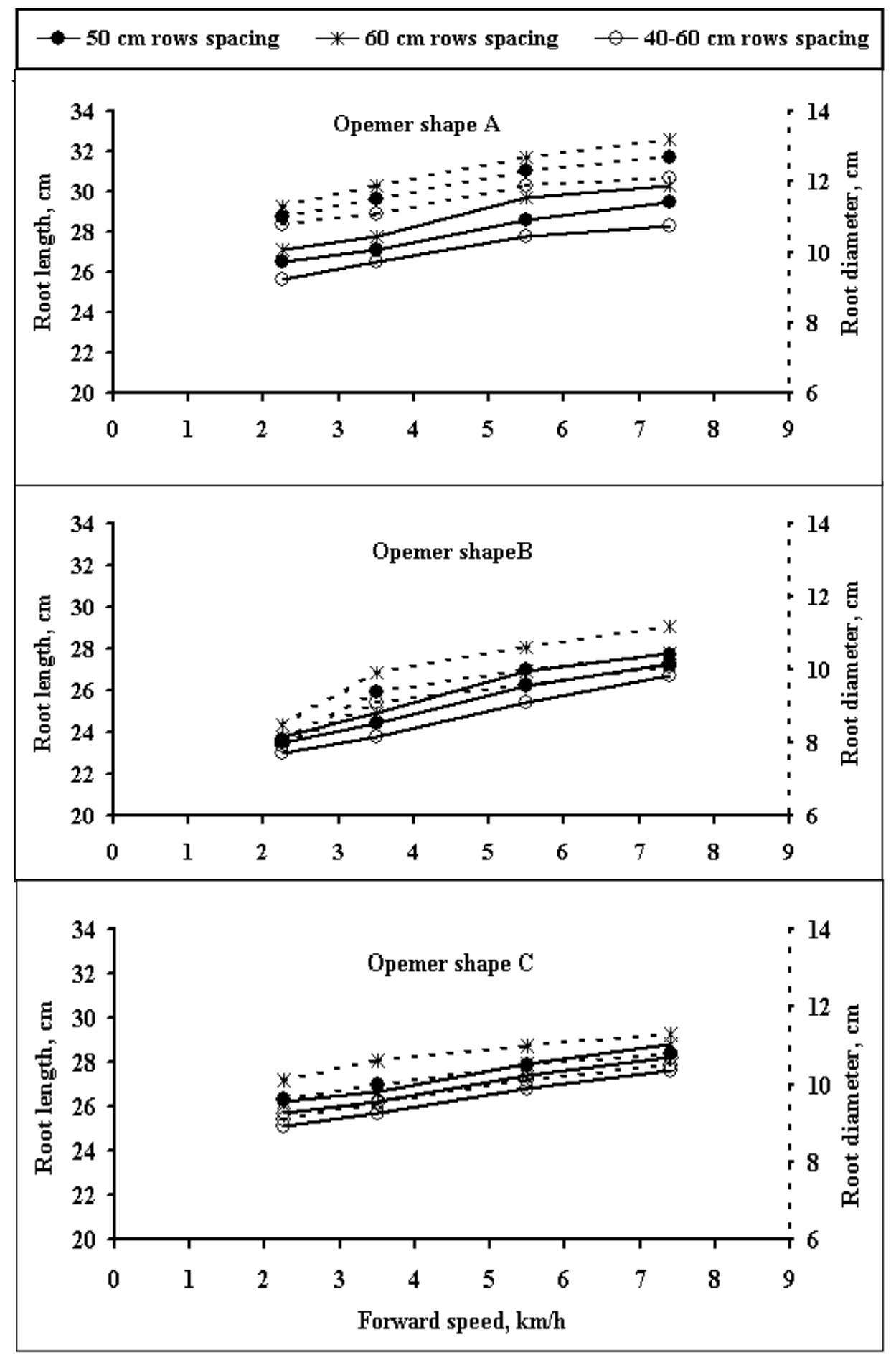

Fig. 5: Root length and diameter as affected by row space and forward speed at different opener shapes. 


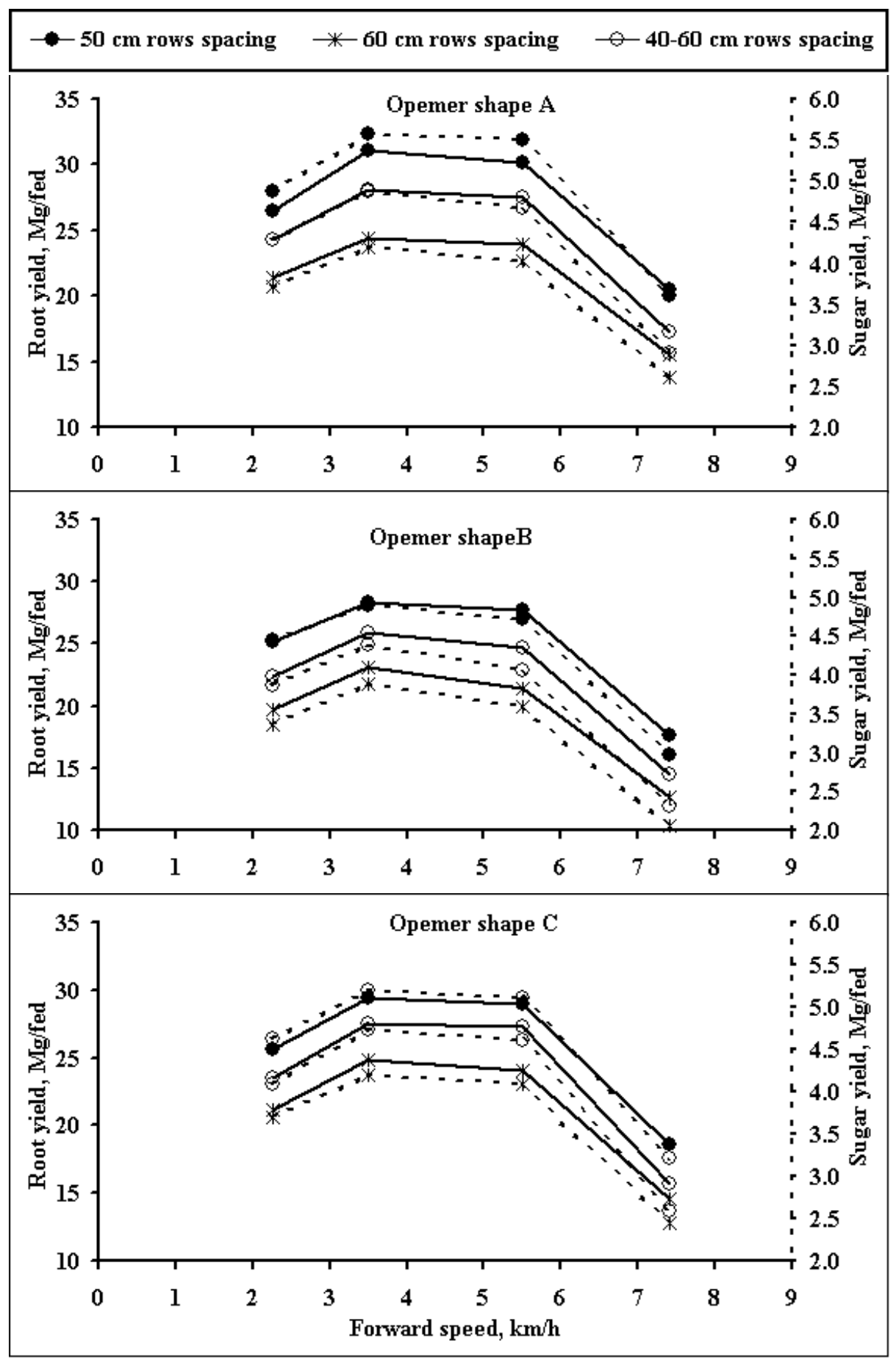

Fig. 6: Root and sugar yield as affected by row space and forward speed at different opener shapes. 


\section{Field water use efficiency:}

Fig.7 shows the effect of forward speed, row space and opener shape on field water use efficiency. It is evident that the row space of $40-60 \mathrm{~cm}$ (ridge) increased the water use efficiency by 32.06 and $69.6 \%$ compared with 50 and $60 \mathrm{~cm}$ row spaces, respectively at forward speed of $5.5 \mathrm{~km} / \mathrm{h}$ and opener (A). This trend was due to decrease the amount of water applied and increasing the sugar beet yield.

The data also indicated that at all forward speeds and, row spaces, the opener (A) achieved the highest values of water use efficiency followed by the opener (C), while the lowest one was obtained from opener (B). The reason for that, the bottom of furrow in case of opener A was wider than the other shapes and no interception through the furrow consequently decreased the amount of water applied.

Concerning to planter forward speed, there was a small effect on water use efficiency.

\section{CONCLUSION}

The main results may be summarized as follow:

1. The minimum values of seed scattering were obtained with 40$60 \mathrm{~cm}$ comparing with other spaces at forward speed of 2.25 $\mathrm{km} / \mathrm{h}$ and opener (A).

2. The highest values of number of plants per feddan and water use efficiency were 44900 plant/fed. and $0.0173 \mathrm{Mg} / \mathrm{m}^{3}$ with $40-60$ $\mathrm{cm}$ row space at forward speed of 2.25 and $3.5 \mathrm{~km} / \mathrm{h}$, respectively with opener (A). flowed by $50 \mathrm{~cm}$ row space. While the lowest one was obtained with $60 \mathrm{~cm}$ row space and forward speed of $7.4 \mathrm{~km} / \mathrm{h}$ when using opener (B).

3.The highest values of root and sugar yield were 31.027 and $5.573 \mathrm{Mg} / \mathrm{fed}$. at $50 \mathrm{~cm}$ row space with furrow opener (A) and forward speed of $3.5 \mathrm{~km} / \mathrm{h}$. 


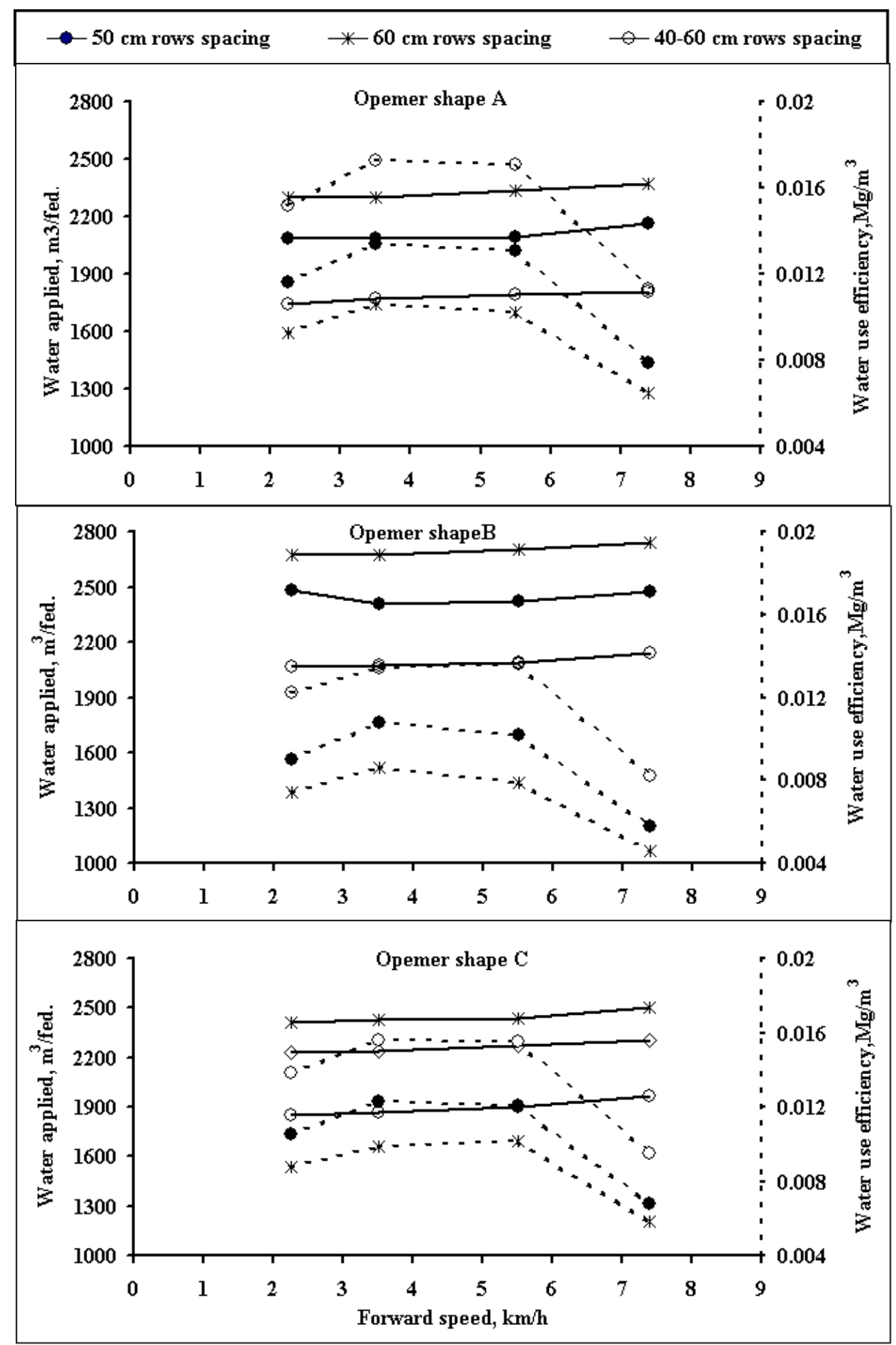

Fig. 7: Water applied and use efficiency as affected by row space and forward speed at different opener shapes. 
4. Increasing the forward speed from 2.25 to $7.4 \mathrm{~km} / \mathrm{h}$ tends to increase longitudinal, transverse scattering, root diameter and length by $144.44181 .25,11.32$ and $15.45 \%$, respectively at 50 $\mathrm{cm}$ row space and opener (A) but the number of plant per fed., sugar and root yield decreased by 24.71,22.98 and $26.09 \%$ respectively at the same above conditions.

5. The opener (A) achieved the heights values of number of plants/fed. sugar and root yield, and water use efficiency followed by opener (C), while the lowest values was obtained from opener (B) at all study parameter.

6. The present study recommended to plant sugar beet seeds by using opener A with $50 \mathrm{~cm}$ row space at forward speed of 3.5 $\mathrm{km} / \mathrm{h}$.

\section{REFERENCES}

Agness, J.B. and H.J. Luth (1975). Planter evaluation techniques. ASAE paper No. 75-1003, ASAE, St. Joseph, MI 49085.

Cattanach, A. and G. Schrooder (1980). A comparison of 22 versus 30 inch row spacing at equal plant populations in 1976-77. 1979 North Dakota-Minnesota sugar beet research and Extensin reports.:98-203.

Fornstrom, K.J. and G. Jackson (1983). Sugar beets planted to stand in 56 and 76 centimeter rows. J. Am. Soc. Sugar Beet Technol., 22(2): 108-118.

Giles, J.F.; A.W. Cattanach; L.J. smith and N.R. Cattanach (1990). Effect of planter ground speed and seed spacing on sugar beet production. J. Sugar Beet Research., 27 (3-4): 3949.

Hull, R. and K.W. Jaggard (1971). Recent developments in the establishment of sugar beet stands. Field Crop Abstracts. 24(3): 381-390.

Eid, S.A. (1998). Surge flow irrigation for corn and wheat under different land leveling practices in heavy clay soils. Ph.D Thesis. Soil Dep., Fac. of Ag. Kafer El-Sheikh, Tanta Univ., Egypt.

Lenka, D. (1991). Irrigating and drainage. First Edition SAn, New 
Delhi,: 175-189.

Michael, A.M. (1978). Irrigation Theory and practice. Vikas Publishing House PTILTD, New Delhi, Bombay.

Robinson, F.E. and G.F. Worker (1969). Plant density and yield of sugar beets in an arid environment. Agron. J. 61: 441-443.

Schwab, G.O.; D.D. Faugmeier; W.J. Elliot and R.K. Frevert (1993). Soil and Water Conservation Engineering. Fourth Edition, Canda,Chapter. 19.

Singh, B. and T.C. Thakur (1979). Sugar beet hand drill for small and marginal farmers in developing countries. AMA., 1(1): 59-63.

Taieb, A.Z. (1997). Comparative study on manual and mechanical sugar beet planting in the newly reclaimed lands. Misr J. Ag. Eng., 14 (3): 299-309.

\section{تطوير آلة زراعة فى جورلتقليل المسافة بين الملخص العربي وتعظيم إنتاجية بنجر السكر

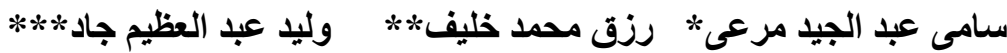

يهدف هذا البحث إلى تطوير آلة زر اعة للبنجرGaspardo Seminatrici S.P.A وذلك بتقالقليل

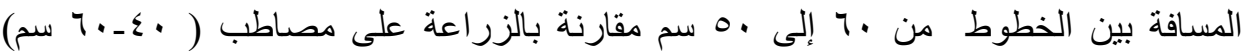

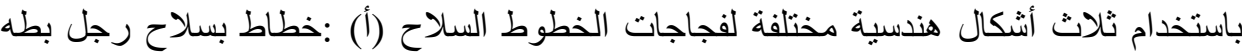

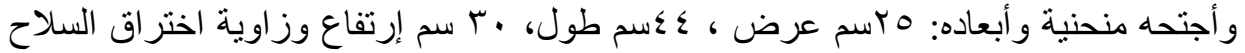

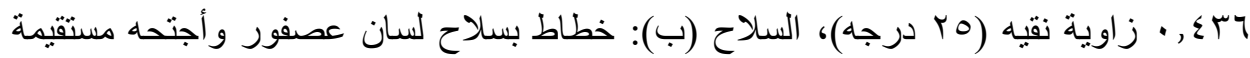

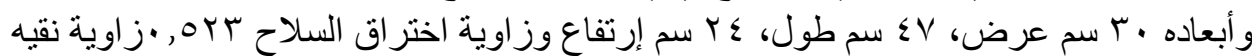

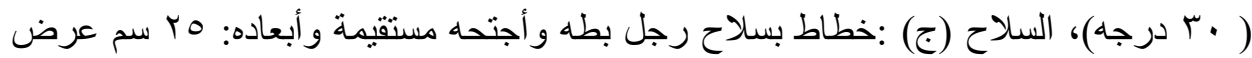

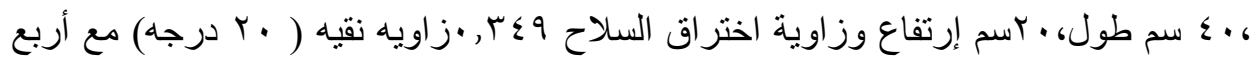

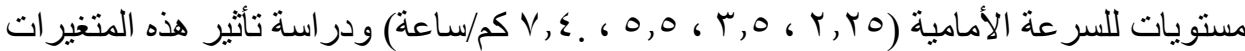

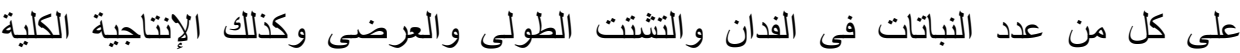
للمحصول ومكوناته وكذللك كفاءة استخدام المياه

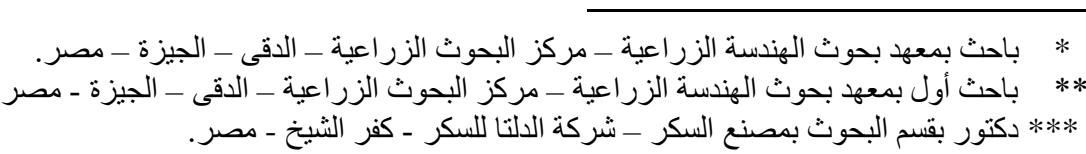


تمت عملية التطوير بمصنع السكر بالحامول بمحافظة كفر الثيخ وأجريت التجارب الحقلية

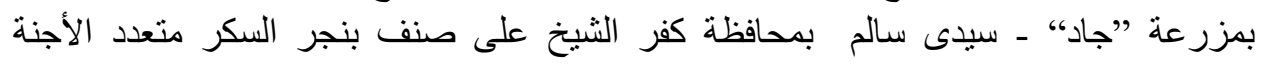

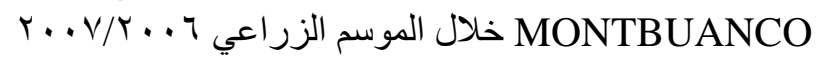
وكاتت أهم النتائج المتحصل عليها كما يأتي:

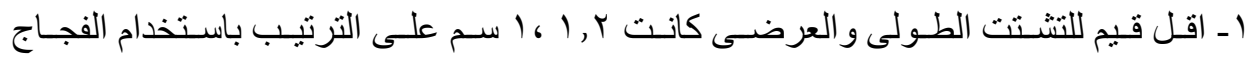

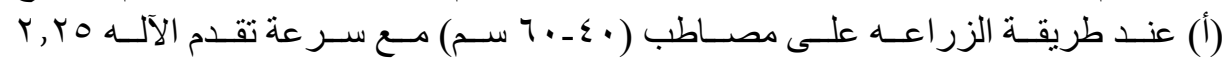
كم/ساعه.

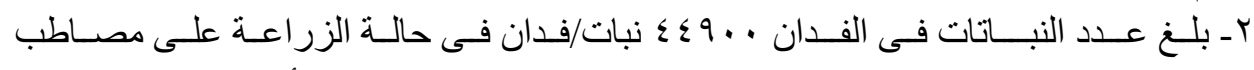

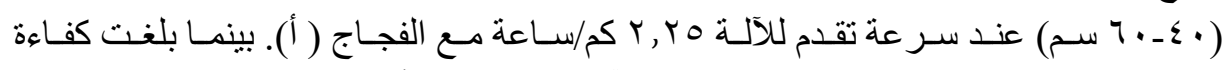

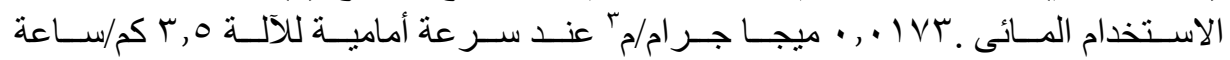
لنفس ظروف التشغيل السابقة.

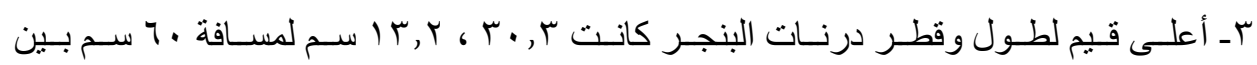

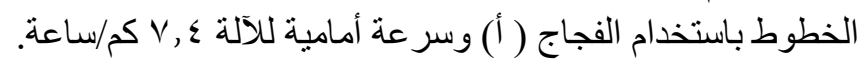

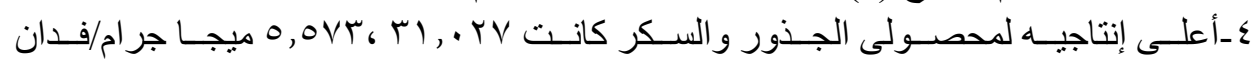

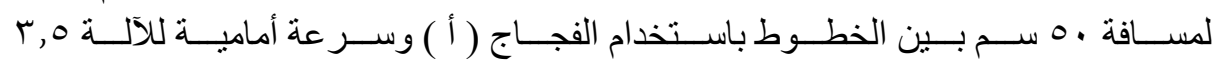

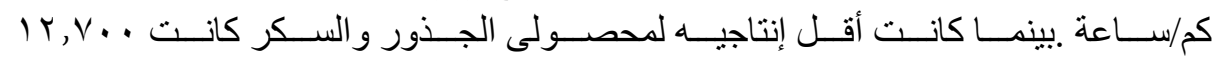

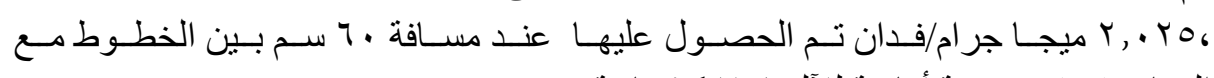

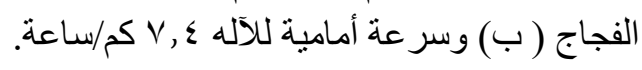

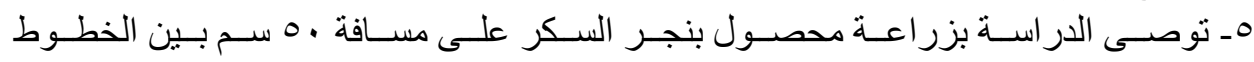

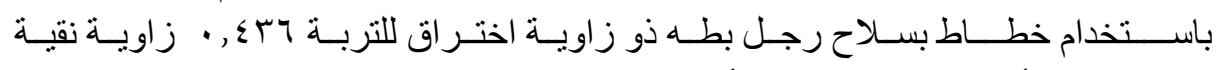

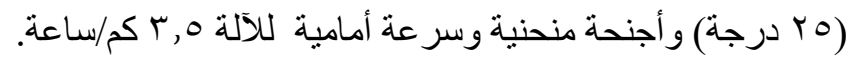

